\title{
The Role Of Corporate Governance Mechanism On Voluntary Disclosure
}

\author{
Andrew Gunawan \\ Fakultas Bisnis dan Akuntansi Universitas Katolik Musi Charitas \\ andrew@ukmc.ac.id
}

\begin{abstract}
Basically, the purpose of this research is to examine empirically whether the Corporate Governance is the proportion of independent commissioners, the commissioners who have accounting capabilities, and the proportion of independent auditors can influence disclosure voluntarily. Voluntary disclosure is measured through the complete disclosure of voluntary index (IPS). This index contains 37 items in disclosure in the annual report. The sample is a manufacturing company listed on the Indonesia Stock Exchange, where the data analysis technique that will use the Multiple Regression Analysis using SPSS 23.
\end{abstract}

Keywords: Corporate Governance, Voluntary Disclosure.

\section{INTRODUCTION}

Basically, the disclosure of annual report information is one of the most important aspects of assessing company performance. Information disclosure is divided into two; mandatory disclosures and voluntary disclosures. Disclosure of its nature must be regulated in the Financial Services Authority (OJK) regulation Number 29 / POJK.04 / 2016 concerning the issuer's annual report on the basis of disclosure of information regulated in the Bapepam-LK Number KEP-431 / BL / 2012. Meanwhile, voluntary disclosure (voluntary disclosure) is outside the scope of required disclosures according to the regulation (Wulandari, 2015).

Voluntary disclosure is often neglected because it is considered not important by both companies and investors (Giovana, 2017). For an example of voluntary disclosures are voluntary information about business expansion and changes in the number of workers. This information is actually an aspect of the main risk assessment of a company. If this information is not disclosed or ignored, it is often the information presented becomes unbalanced, in the basic sense of evaluating the overall performance of a company, especially a company going public, becomes irrelevant.

Some cases have shown how companies are considered "good" experiencing business setbacks or even bankruptcy. An example is the case of Batavia Air, which is one of the largest airlines in Indonesia. This company is expanding its business without disclosing it to the public. The business expansion was done by renting an Airbus aircraft from the International Lease Finance Corporation (ILFC) and causing a debt of approximately $\mathrm{Rp} 2.5$ trillion which was only discovered in 2003 after surprisingly the company was declared bankrupt (Sindonews.com). 
Another example that happened at PT. Citra Maharlika Nusantara Corpora Tbk. which was declared bankrupt on April 27, 2017, even though the company's performance was classified as good. The main reason for the bankruptcy of this company is the result of debts accumulated as a result of uninformed capital expenditure. In addition to the two companies above, the most shocking news was the bankruptcy of PT. Nyonya Meneer on August 3, 2017. Even though the company's track record from 1919 to the present is fairly good, even the products have penetrated the international market. The news that blew debts due to the modernization of unpublished production equipment was one of the causes of the bankruptcy of this company (detik.com). The most recent incident occurred at PT. Three Pillars of Prosperous Food were temporarily frozen while trading their shares by IDX as of July 5, 2018. Meanwhile, the issuer with the AISA code is one of the giants in Indonesia's food and beverage sector.

These phenomena have clearly shown the importance of disclosure of information, especially those that are voluntary (voluntary disclosure). If this is not done, it will cause investors and creditors to be unable to carry out relevant assessments of both the opportunities and risks borne by the company in particular. Companies that are often considered "good" are not necessarily good in the real sense; this is due to a lack of supporting information that is not a component of mandatory disclosures.

Basically, the main factors that influence disclosure of information, especially those that are voluntary, are corporate governance mechanisms (CG) (Amalia et al., 2013). (Daniri, 2014) defined that the CG mechanism is an embodiment of added value to all company stakeholders legally formal and comprehensive by maximizing the role of corporate structures such as directors, a board of commissioners and general meeting of shareholders. The CG mechanism is how a company manages its business. In addition, (Achmad, 2012) in his research entitled "Board of Commissioners and Transparency" revealed that the existence of an independent board of commissioners is very important in carrying out the oversight role of governance in a company. This is because the business management is carried out with a good corporate governance mechanism; transparency of actual conditions will be expressed more through the voluntary component of information (voluntary disclosure).

A good corporate governance mechanism is indicated by the proportion of independent commissioners. The proportion of independent commissioners directly acts as "supervisors" and "controllers" of all business activities in the company. Independent board of commissioners basically has better transparency compared to ordinary board of commissioners. This is due to the absence of special or transactional relations with the company in which they are based. In order to create relevant internal controls, the board of commissioners appoints and forms an audit committee (Kasmadi and Susanto, 2014). Based on the Decree of Bapepam-LK Number KEP29 / PM / 2004, the audit committee is defined as a committee that functions to run the supervision and management mechanism of the company and is systematically formed by the board of commissioners.

Basically, the audit committee has the task of supervising and managing the company. The audit committee has a function as a liaison between shareholders and the board of commissioners and management in terms of internal control. Thus, the more independent the audit committee is owned by a company, the better control of the 
company will be. Good control will result in agency conflicts that occur as a result of management's desire to improve its own welfare can be minimized.

Apart from these two factors, the proportion of board of commissioners has accounting and business capabilities which are broad supporting factors for voluntary disclosure in the company. The more the number of board of commissioners who have accounting or business skills, it is expected to minimize conflicts of interest that occur in a company. When conflicts of interest are eliminated, it is expected that the level of disclosure of voluntary information (voluntary disclosure) in the company will be broader.

Most previous studies focused more on research related to the effect of corporate governance on voluntary disclosure so that similar studies are rarely found. For example, (Nancy, 2012) research which focuses more on corporate governance variables than good corporate governance, which is represented by variable institutional ownership, foreign ownership, independent commissioners on voluntary disclosure. The result showed that foreign ownership, institutional ownership, and independent commissioners have no effect on voluntary disclosure.

This result is contrary to the research conducted by Barako (2007) entitled "Determinants of Disclosure of voluntary in Kenyan Companies Annual Reports". The result of the study indicated that there is a positive relationship between the board of independent commissioners and the audit committee on voluntary disclosure. This showed that there are differences in the result of research specifically on the influence of independent board of commissioners which is a component of corporate governance on voluntary disclosure. Because of these conditions, other determinant variables such as the board of commissioners have mastered accounting practices, with the hope that when a board of commissioners controls accounting, it will tend to reveal more types of information-type information, especially voluntary information in the publication of financial statements.

\section{THEORETICAL REVIEW}

Agency Theory. Basically, the agency theory principle proposed by (Jensen and Meckling, 1976) is the existence of a working relationship between the principal (the owner as of the authorizing party) and the management represented by the manager (the recipient of the authority). With the establishment of this cooperative relationship, it directly or indirectly raises a potential "conflict". The conflict in question is a difference of interests, meaning that between the authorities (owner) and the recipient of authority (manager) have different goals in fulfilling their respective ambitions or desires. For example, owners as principals want their company to progress significantly, while managers who act as agents are more interested in maximizing their own welfare and prosperity compared to the prosperity of the company.

Continuous on interest conflicts between the owner (principal) and the manager (agent) will cause a new problem, imbalance in the absorption of information from the two parties in conflict, or often referred to as information asymmetry. This arises because managers who act as agents and direct implementers of company activities have far more complete information than the owners who act as principals. This certainly affects the only means of corporate communication with external parties, such as financial statements. 
Information asymmetry will make the information contained in the financial statements "bad" and make investors or other external parties evaluate "blur".

If it is associated with voluntary disclosure it is reasonable. Basically, differences in interests will affect the size of the information published by the company, especially information that is voluntary (Khairiah, 2017). This means that information asymmetry clearly occurs with the assumption that management does not want all internal information, especially those that are voluntary, that external parties, including investors, are aware of.

Information Asymmetry Theory. Information asymmetry is a concept where management generally has more information about the company's internal conditions, compared to external parties such as shareholders, the public, and the government. In practice, investors and stakeholders should obtain the information needed including disclosure of voluntary disclosures, but in fact, the information obtained by managers is not entirely presented to investors and stakeholders (Novita, 2013).

As a result, information obtained by investors and stakeholders is incomplete hence, it still cannot be explained the actual performance of managers in managing the principal wealth entrusted to the agent. In the end, information imbalance which is an implication of the difficulty of the owner or principal in controlling and supervising the behavior and actions of managers or agents causes new problems in moral hazard and adverse selection (Mohamed, 2013). Moral hazard is an anomaly where the manager or agent does not carry out his duties to the maximum extent as stated in the collective agreement in the form of a work contract. Obviously, it is caused by the manager's negative behavior that arises because it prioritizes personal interests.

Adverse selection is a form of agent's decision that is carried out unilaterally without the knowledge of the principal or owner, or the decisions are taken are not in line and are not in line with the company's goals in general. Just like the previous problem, this also occurs as a result of the inability to control and control manager behavior (Devrimi, 2014). To reduce these two problems, the mechanism of good corporate governance is urgently needed, as is the proportion of independent commissioners, the proportion of commissioners who master accounting practices, and independent audit committees. These three aspects are means of control and supervision that are quite effective in overcoming the problems mentioned above.

Voluntary Disclosure. In general, the types of disclosures in annual reports are divided into two, mandatory disclosures and voluntary disclosures (Davide, 2016). Mandatory disclosure is information that is required to be published by the company, especially by using intermediary media such as financial and annual reports. All capital market and financial institution activities in Indonesia include the disclosure of annual reports regulated by the Capital Market and Financial Institution Supervisory Agency (BapepamLK), which has now been renamed the Financial Services Authority (FSA) (Krishna and Satriajaya, 2013). To regulate disclosures in financial reports and annual reports, Bapepam-LK issued a regulation Number KEP-431 / BL / 2012 concerning the submission of annual reports of issuers or public companies. Voluntary disclosure is a disclosure that is not required by regulation. Unlike mandatory disclosures, voluntary 
disclosures are not regulated in Bapepam-LK regulations Number KEP-431 / BL / 2012. In conducting voluntary disclosures companies are given the freedom to disclose; therefore it can cause many variations of information provided by each company (Nurrunabi, 2012).

The type of disclosure information consists of 105 types of information disclosed. The overall type of information was obtained from the 2006 Indonesian General GCG Guidelines. All types of disclosure information were examined and adjusted for the type of voluntary disclosure information used in (Barako's, 2007) study to be a total of 43 types of information. Thus, these studies, 43 types of information were adjusted to the BapepamLK regulations Number KEP-431 / BL / 2012. There are 6 types of information that were originally voluntary disclosures as mandatory disclosures. The types of information are the ability and integrity of the board of directors, the ability and integrity of the board of commissioners, the duties and independence of the audit committee, information of the Internal Audit Unit, the contents of corporate ethics, regulations that ensure the harmony of the company and the surrounding community and its existence. As a result of these changes, the type of information on voluntary disclosure consists of 37 types of information with general and strategic information (9 types of information), economic data (7 types of information), future prospects (8 types of information), social and board (13 types of information))

In detail, general and strategic information categories consist of the company's vision and mission, company history, organizational structure, explanation of production and products to be produced by company's contribution to the national economy, business strategy, company stock development, intra-industry competition, regional economic improvement. For economic indicators consisting of a summary of minimum financial data for the past six years or more, analysis of the company's current financial results, analysis of factors that trigger company performance, aspects of inflation, company financial ratios, refunds to shareholders, company liquidity ratios.

The indicators of the company's prospects include the triggers of the company's future performance, the implications of business strategies on company performance, research, and development of new products, capital expenditure plans, research and development budgets, marketing and publication budgets, projected earnings per share, profit projections. Finally, the category of social disclosures and councils consists of the number of workers for the last two years minimum, arguments for changes (addition or reduction) in the number of workers, labor productivity ratios, indicators of labor productivity, morale and discipline of workers, work accident data, community participation, director profile including name and age, qualifications, business experience, and stake ownership of interested parties such as directors and other management.

The entire categorical information above is information that is voluntary (freely disclosed or not) by the company, but in fact, will be critical information. The critical information in question is primarily related to the assessment of the condition of the company appropriately and relevantly.

Corporate Governance. Basically, a company's governance mechanism has two management aspects, internal and external parties. External management mechanisms will be carried out by outsiders called outsiders. The outside parties referred to are capital 
market mechanisms, and banks or financial institutions that lend funds to companies. In addition to these two parties, those included in other external controllers are the community as consumers, suppliers, employees, and the government as regulators.

Meanwhile, internal management segmentation is manifested in the form of a board of commissioners and the ranks below such as the board of directors, audit committee, and other management. Both of these management segmentations basically have the same goal; carry out comprehensive control and supervision of management behavior within the company. More specifically, these two segments will be used for early detection and warning, making overall improvements to the company before entering the critical phase. This is the main task and responsibility of the board of commissioners or in other words, corporate governance itself is an absolute and complex task that integrates internal and external segments in preventing negative actions that may arise from management acting as agents in the management of the company.

In this case, the company must have a system and supervision in addition to the internal segment that oversees all fields in the company's operations and non-operations, such as finance, risk control, and compliance. The entire task is the responsibility of the audit committee and the independent board of commissioners. From the statement above, it can be defined corporate governance mechanisms to be the relationship between several related organs, such as the proportion of independent commissioners, the proportion of board of commissioners who have accounting or business capabilities, the proportion of independent audit committees. The board of commissioners is the culmination of an internal management system so that it has a very important role in the company's operations. The role of the board of commissioners includes ensuring the strategic implementation of the company, overseeing management in managing the company, and realizing transparency. The role of the board of commissioners will be supported if they carry out their duties independently so that they will increase the level of transparency in a voluntary disclosure.

The board of commissioners has accounting capabilities also thought to have an important role in a voluntary disclosure. Because they are more sensitive and know what information needs are needed by stakeholders to assess the company. This is inseparable from the desire to provide a positive signal in the form of information transparency, especially the company's financial information which will ultimately lead to positive sentiments also by stakeholders.

Basically, the audit committee plays an important role in the mechanism of controlling corporate governance (Mishari and Abdullah, 2017). According to BapepamLK Decree Number KEP29 / PM / 2004, the audit committee is defined as a committee that has the main function in overseeing the management of the company and is a communication bridge between commissioners, major shareholders, and company management, especially the formulation and implementation of good internal control mechanisms. That is, with the existence of an independent audit committee or not having an interest in the company, the supervision, and control of company activities becomes more effective and efficient especially to prevent the impact of differences in interests and information asymmetry that occurs. 
Development of Hypotheses. Basically, the existence of a board of commissioners holds the function of controlling the amount of information related to voluntary disclosure (voluntary disclosure). Generally, the board of commissioners tends to limit the amount of information on voluntary disclosures if the information is assembled with something that is considered "confidential" or can "endanger" the company's position in the eyes of stakeholders. But it can be neutralized by the proportion of board of commissioners that is independent, which is one form of corporate governance mechanisms (Poh Ling Ho and Taylor, 2013). Independent boards tend not to have conflicts of interest and will be more open in terms of transparency voluntary disclosure of information. Therefore, the first hypothesis in this study is:

H1: The proportion of independent commissioners has a positive effect on voluntary disclosure.

The board of commissioners has accounting and business knowledge and can be expected to be able to encourage entities to make voluntary disclosures (Wen $\mathrm{Qu}, 2013$ ). This is because, they have accounting and business skills, and they are expected to know what voluntary information should be expressed as a form of transparency to encourage the creation of positive sentiments for stakeholders. Based on this argument, the second hypothesis in this study is:

H2: The proportion of board of commissioners having accounting and business skills has a positive effect on voluntary disclosure.

In addition to independent commissioners having accounting and business capabilities, audit committees also play an important role in determining the broad amount of voluntary disclosure of information (voluntary disclosure). The main independent audit committee is expected to encourage more disclosure of voluntary information because they do not have any interest in the company (Wijayanti, 2013). From that the third hypothesis in this study is:

H3: The proportion of independent audit committees has a positive effect on voluntary disclosure.

\section{METHODOLOGY}

The scope of research. The scope of this research is all manufacturing companies listed on the Indonesia Stock Exchange since 2015 - 2017. Manufacturing companies are taken because this sector dominates the Indonesia Stock Exchange hence; it is expected to represent the entire sector. While the observation period is only 2015-2017, considering that in this period there were many phenomena where companies that were considered "good" experienced setbacks or even bankruptcy as happened at PT. Nyonya Meneer.

Population and Samples. The population in this study is all manufacturing companies listed on the Indonesia Stock Exchange since 2016 - 2017. The sampling technique used in this study was purposive sampling, with the criteria: Manufacturing companies with 
consumption sub-sectors that have been registered or have just registered on the IDX throughout the period observations in 2015 - 2017 and publish its annual report. This is because the phenomena related to bankruptcy and business setbacks occur mostly in the consumption sector, such as PT. Three Pillars of Prosperous Food and PT. Nyonya Meener.

Types and Data Sources. In this study, researchers used secondary data. Data from manufacturing companies listed on the Indonesia Stock Exchange and annual report data for measuring research variables are obtained from direct access to the site www.idx.co.id or through the IDX corner of Unika Musi Charitas.

Method of collecting data. The method of collecting data is by using documentation techniques. The source can be in the form of information or annual reports from the Indonesia Stock Exchange and the company's website or the website itself.

Operational Definition and Variable Measurement. The dependent variable in this study is voluntary disclosure measurement. In this study, we will use a disclosure index based on Bapepam-LK Number KEP-431 / BL / 2012, which is 37 items of information. The formula is:

$$
\operatorname{IPS}(\mathbf{Y})=\frac{\Sigma Q}{\Sigma S}
$$

Information:

IPS $=$ Complete voluntary disclosure index

$\sum \mathrm{Q}=$ Items complete with voluntary disclosures in the annual report

$\sum \mathrm{S}=\mathrm{All}$ items are complete expected voluntary disclosures

The independent variables in this study are corporate governance mechanisms that are proxied through the proportion of independent commissioners, the proportion of board of commissioners who have accounting and business skills, and the proportion of independent audit committees. Where to estimate these three independent variables is done by:

Independent Board of Commissioners (X1):

(Number of Independent Commissioners)

(Number of Board of Commissioners)

Board of Commissioners is capable of accounting or business (X2):

(Total Board of Commissioners with Accounting or Business Ability)

(Total Board of Commissioners)

Independent Audit Committee (X3):

(Number of Independent Audit Committees)

(Number of Audit Committees) 
Data analysis technique. The data analysis technique that is used in this study is multiple regression analysis using SPSS version 23 . The regression models used in this study are:

$$
\mathrm{VD}=\beta 0+\beta 1 \mathrm{DKI}+\beta 2 \mathrm{DKAB}+\beta 3 \mathrm{KAI}+\varepsilon
$$

Information:

VD: $\quad$ Voluntary disclosure

B0: $\quad$ Constants

DKI: $\quad$ Independent Board of Commissioners

DKAB: $\quad$ Board of Commissioners with Accounting or Business Ability

KAI: $\quad$ Independent Audit Committee

$\varepsilon$ : $\quad$ Standard error

Before conducting a multiple regression analysis, researchers will first conduct a descriptive statistical test. After that, to ensure that the regression model created above can be used to test the hypothesis, and then the regression model is tested (Ayu, 2013). Testing the regression model is done so that the regression model used can answer the hypothesisfree from problems such as normality of the data; therefore it is necessary to screen data. After screening the data, the next step is to test classic assumptions such as multicollinearity, Heteroscedasticity, autocorrelation.

Descriptive statistics. Basically, descriptive statistics are used to provide a description or description of data by showing the average value (mean), standard deviation, variance, maximum and minimum (Ghozali, 2012). The measurement of descriptive statistics used is the mean, standard deviation, maximum, minimum.

Data Screening. Before conducting statistical tests, the first step that must be done is screening the data to be processed. The data screening technique used is data normality testing. Test the normality of data using the Kolmogorov - Smirnov non-parametric statistical test with a significance level of $5 \%$.

Classic assumption test. The classic assumption test that will be used in this study includes three tests, such as:

Test multicollinearity. Basically, a good regression model is a model that is not exposed to multicollinearity problems in it. According to (Ghozali, 2012) that in assessing whether a model is infected with multicollinearity problems can be done by paying attention to the value of tolerance and Variance Inflation Factor (VIF). It is stated to be free from multicollinearity if the tolerance value ranges from 0.1 to below 1 , while the VIF faction value ranges from 1 to below the number 10 . This only applies to simple and multiple linear regression models, does not apply to moderation and mediation models.

Heteroscedasticity test. Variance is one of the factors that determine whether the model is infected with symptoms of Heteroscedasticity or not. A good research model has the same coefficient of variance from one residual data to another residual. According to 
(Ghozali, 2012), Heteroscedasticity testing can use the glacier method. A good model will have a critical value of a significant probability of more than 0.05 at a 5\% confidence level in order to prove that the data in the study are free from symptoms of Heteroscedasticity.

Autocorrelation Test. The autocorrelation test is used to show the correlation between data errors from one period to another. If there is a correlation, then there is an autocorrelation problem. According to Imam (Ghozali, 2012), the autocorrelation test can use the Durbin Watson method or run test. In this study, the method used is DurbinWatson, where a group of data will not be affected by autocorrelation problems if the DW value is between the $\mathrm{dU}$ value and between the 4-dU values.

\section{THE RESULT OF CLASSICAL ASSUMPTION TEST}

Normality test. Normality test aims to test the confounding / residual variables with normal distribution or not. The Kolmogorov-Smirnov (K-S) non-parametric statistical test has criteria that are normally distributed if the value of Asymp. Sig.(2-tailed) above 0.05. The result of the normality test can be shown in table 1 .

Table 1. The Result of Normality Test

\begin{tabular}{lr}
\hline Explanation & Unstandardized Residual \\
\hline $\mathrm{N}$ & 68 \\
Test Statistic & 0,175 \\
Asymp. Sig. (2-tailed) & 0,000 \\
\hline
\end{tabular}

Source: (SPSS 23 Output)

Based on this result, the data in this study can be obtained to be abnormal because the significance value is less than 0.05. According to (Santoso, 2014), if the data in the study are not normal, then there are four ways that can be done:

1. Add data observation period

2. Using data as is

3. Perform statistical surgery by means of outliers, winsorize, and transform

4. Change the parametric method to non-parametric

Based on these four methods, researchers have tried to add to the observation period of data, from the previous one year to 2 years of observation, 2016-2017, but the data remains declared abnormal. Then the researchers tried to do statistical surgery by means of transformers and outliers by removing $\mathrm{z}$ score values that were greater than 2 and smaller than -2 . The result obtained is:

Table 2. The Result of Normality Test after Outliers

\begin{tabular}{lr}
\hline Explanation & Unstandardized Residual \\
\hline $\mathrm{N}$ & 62 \\
Test Statistic & 0,172 \\
\hline
\end{tabular}




\begin{tabular}{lc}
\hline Asymp. Sig. (2-tailed) & 0,000 \\
\hline
\end{tabular}

Source: (SPSS 23 Output)

Based on the result of table 2 it can be shown that the data of this study still does not meet normality, therefore the researcher uses the next method, by changing the testing method to non-parametric by using bootstrapping. Bootstrapping is a non- parametric test method that does not require the fulfillment of classical assumptions, but has weaknesses in testing the parameters of this study.

Test of Determination Coefficient Test. The coefficient of determination (R2) is used in this study to test the goodness of fit regression model used. This coefficient basically measures how far the model's ability to explain the variation of independent variables (Ghozali, 2012). The result of the coefficient of determination in the regression model can be shown in table 3 .

Table 3. Coefficient of Determination

\begin{tabular}{cc}
\hline Model & Adjusted $R$ Square \\
\hline 1 & 0,304 \\
\hline
\end{tabular}

Source: (SPSS 23 Output)

From the value of Adjusted R Square in the research model, the result is 0.304. This means that the independent variable in the model is able to explain the dependent variable by $30.4 \%$.

Test F. In the F statistical test, a regression model is stated to be feasible or good to use if the significance value is above 0.05 . The result of the F statistical test can be shown in table 4.

Table 4. The Result of Statistics F-test

\begin{tabular}{cc}
\hline Explanation & Sig. \\
\hline Regression & $0,000^{\mathrm{b}}$ \\
\hline
\end{tabular}

Source: (SPSS 23 Output)

The result of processing data through the ANOVA test is shown that the significance value is 0,000 below 0.05 . This means that the model in this study is feasible to use.

T-test. In conducting hypothesis testing, multiple linear analysis models are used. The result of hypothesis testing can be shown in table 5 .

Table 5. Result of Statistics test for t- Multiple Linear Regression

\begin{tabular}{cccc}
\hline Variables & B & Sig. & Conclusion \\
\hline (Constant) &, 438 &, 002 & \\
\hline DKI &,- 081 &, 787 & H1 rejected \\
\hline
\end{tabular}




\begin{tabular}{cccl}
\hline DKA &, 643 &, 002 & H2 accepted \\
\hline KA &, 064 &, 544 & H3 rejected \\
\hline
\end{tabular}

Source: (SPSS 23 Output)

Based on the result of statistics t-test, it can be explained as follows:

The regression result equation

$\mathrm{VD}=0.438-0.081 \mathrm{DKI}+0.643 \mathrm{DKA}+0.064 \mathrm{KA}+0.047+\mathrm{e}$

From the result of statistics t-test with a 95\% confidence coefficient, it can be shown that:

1. The regression equation showed that the constant value is 0.438 , which means that if the independent variable is the proportion of independent commissioners, the proportion of commissioners who have accounting or business capabilities, the proportion of independent audit committees is 0 or ignored, the value of voluntary disclosure is 0.438 .

2. The significance probability value of the variable proportion of independent commissioners represented by DKI is 0.787 . This value is greater than 0.05 and the beta coefficient is negative, thus, it can be concluded that partially the independent commissioner variables have no effect on voluntary disclosure.

3. A significant probability value of the variable proportion of the board of commissioners who have accounting or business capabilities denoted by DKA is 0.02 . This value is smaller than 0.05 and the beta coefficient is positive, thus, it can be concluded that partially the board of commissioners variables that have accounting or business skills have a significant positive effect on voluntary disclosure.

4. The significance probability value of the independent audit committee proportion variable represented by KAI is 0.544 . This value is greater than 0.05 and the beta coefficient is positive, and it can be concluded that partially the variable proportion of the independent audit committee has no significant effect on voluntary disclosure.

\section{DISCUSSION}

Corporate information disclosure is one of the main problems faced by stakeholders in Indonesia. And this can be shown from the number of companies that look "healthy" but in fact are very problematic, for example, PT. Citra Maharlika Nusantara Corpora Tbk, and PT. Three Pillars of Prosperous Food Tbk which are considered to have good performance and track record must be frozen. This incident is indicated as a result of the low level of information disclosure, especially voluntary information, which in turn has an impact on the low accuracy of stakeholder assessments, especially the shareholders' assessment of the company's performance and sustainability.

Basically, there are several aspects of governance within a company that can theoretically overcome the problem of information disclosure primarily over the broad disclosure of voluntary information (Bader, 2013). The governance aspect in question is 
the proportion of independent commissioners, the proportion of board of commissioners who master accounting practices, and audit committees. Based on the result of multiple linear regression tests, it is known that only the board of commissioners' variable that controls accounting has a significant positive effect on the extent of voluntary disclosure, while the proportion of independent commissioners and audit committees does not have a significant effect.

Information disclosure to the public can be indicated by a large number of voluntary (voluntary) disclosures, not from voluntary (mandatory) information (El-Diftar et al., 2017). With the board of commissioners who understand accounting and business practices, it will have an impact on increasing control of company management, especially on aspects of information disclosure to the public which have been a major concern in overcoming the problem of differences in interest and information asymmetry in a company. It is shown that the existence of the board of commissioners was able to encourage the entity to disclose more voluntary (voluntary) information. In addition, the existence of a board of commissioners who master accounting and business will make the company aware of any voluntary information that must be disclosed as a form of transparency to encourage the creation of positive sentiments for stakeholders.

In line with was stated by (Hany and Emad, 2017), the positive sentiment of stakeholders will ultimately implicitly improve the "image" of the company and have an impact on evaluating the performance of a company in a non-financial manner. In addition, according to (Rachmawati, 2016), information disclosure will also affect the achievement of profits of a company in the future. This is the ultimate goal of information disclosure in the form of extensive voluntary information disclosure. Meanwhile, for independent commissioner variables, it has not been able to influence the extent of voluntary consolidation because most of the listed IDX manufacturing companies have a proportion of independent commissioners that are smaller than general or non-independent commissioners in a company. For example, just a company from the same class as Kalbe Farma only has 3 independent commissioners out of a total of 7 independent commissioners', even there are companies that only have 1 independent commissioner. Of course, it will minimize the push for voluntary information disclosure itself.

Related to the audit committee variable, basically, it does not have a role that is extremely big in pushing for broad voluntary disclosures. Moreover, basically, they are only focused on mandatory disclosures rather than voluntary disclosures (Braam, 2014). And it is quite reasonable for the priority in an internal audit that is more on mandatory disclosures which must be fulfilled as a condition of listing on the IDX.

\section{CONCLUSION AND SUGGESTIONS}

Conclusion. Based on the results of the previous discussion, it can be concluded that only the board of commissioners' mastered accounting which was able to encourage extensive voluntary disclosures in consumption sector companies on the IDX. Because they have an understanding related to any voluntary information that can lead to positive perceptions for investors and potential investors. With this understanding, they will exercise more comprehensive control and supervision of company management and will further encourage company management to transparently disclose information, especially in the 
category of voluntary information that is not required by the Financial Services Authority to disclose.

Suggestions. There are several suggestions that can be used in further research,

1. It can be suggested for researchers to then take samples in other sub-sectors such as banking. The banking sector was chosen given the phenomenon where the development of the number of banks in Indonesia continued to decline from year to year.

2. In addition, it is also recommended for future researchers to try to use parametric methods so that the parameters studied become clearer and more valid results.

\section{REFERENCE}

Achmad, Tarmizi. (2012) "Dewan Komisaris dan Transparansi". Jurnal Keuangan dan Perbankan. Vol. 16. No. 1, Agustus 2012. Hal 62-73.

Amalia, Frida and Laksito. (2013). "Pengaruh Mekanisme Tata Kelola Perusahaan Terhadap Luas Pengungkapan Informasi Strategis Pada Website Perusahaan (Studi Empiris pada Perusahaan Manufaktur Yang Terdaftar Di Bursa Efek Indonesia Tahun 2010)". E-Journal Universitas Diponegoro. Vol. 02. No. 01, Januari 2013. Hal 1-11.

Ayu, I Gusti. (2013). "Pengaruh Good Corporate Governance terhadap Pengungkapan Lembaga Perkreditan Desa di Kecamatan Mengwi Kabupaten Badung”. E-Jurnal Akuntansi Universitas Udayana. Vol. 5. No. 3, April 2013. Hal 586-598.

Bader Al-Shammari. (2013). "An Investigation of Voluntary Disclosure By Kuwaiti Shariah-Compliant Companies". Journal of Economic and Administrative Sciences, Volume: 29 Issue 1.

Bapepam-Lk. (2004). Keputusan Ketua Badan Pengawas Pasar Modal Nomor: Kep29/PM/2004 tanggal 24 September 2004 tentang Pembentukan dan Pedoman Pelaksanaan Kerja Komite Audit. Jakarta.

Bapepam-Lk. (2012). Keputusan Ketua Badan Pengawas Pasar Modal dan Lembaga Keuangan Nomor: Kep-431/B1/2012 Tentang Keputusan No X.K.6. tanggal 1 Agustus 2012 tentang Penyampaian Laporan Tahunan Emiten atau Perusahaan Publik. Jakarta.

Barako, Dulacha G. (2007). "Determinants of Pengungkapan sukarelas in Kenyan Companies Annual Reports". African Journal of Bussiness Management. Vol.1. No. 15, Juli 2007. Hal 113-128.

Braam, Borghans. (2014). "Board and auditor interlocks and voluntary disclosure in annual reports". Journal of Financial Reporting and Accounting, Volume: 12 Issue: 2 .

Davide, Scaltrito. (2016). "Voluntary Disclosure in Italy: Firm-Specific Determinants an Empirical Analysis of Italian Listed Company". Euromed Journal of Business, Volume: 11, Issue: 2.

Daniri, Mas Achmad. (2014). Lead By GCG. Jakarta: Gagas Bisnis Indonesia.

Devrimi. (2014). "The Influence of Firm-Specific Characteristic on The Extent of Voluntary Disclosure in XBRL: Empirical Analysis of SEC filings". International Journal of Accounting \& Information Management, Volume: 22, Issue 1. 
El-Diftar, Jones, Ragheb. (2017). "Institutional investors and voluntary disclosure and transparency: the case of Egypt". Corporate Governance: The international journal of business in society, Volume: 17 Issue: 1.

Ghozali, Imam. (2012). Aplikasi Analisis Multivariate dengan Program IBM SPSS. Yogyakarta, Badan Penerbit Universitas Diponegoro.

Giovana. (2017). "The role of the board voluntary disclosure". Corporate Governance: The international journal of business in society, Volume: 18 Issue: 5.

Hany Kamel, Emad Awadallah. (2017). "The extent of voluntary corporate disclosure in the Egyptian Stock Exchange: Its determinants and consequences". Journal of Accounting in Emerging Economies, Volume: 7 Issue: 2, 2017.

Jensen and Meckling. (1976). "The Theory Of The Firm: Manajerial Behavior, Agency Cost, And Ownership Structure". Journal Of Financial And Economic. 3:305-360.

Kasmadi dan Djoko Susanto. (2014). "Analisis Faktor-Faktor yang Mempengaruhi Luas Pengungkapan Sukarela dalam Laporan Tahunan Perusahaan-Perusahaan di Indonesia". Jurnal Akuntansi dan Manajemen. Vol. 12. No. 3. Hal 71-88.

Khairiah, Raidah. (2017). "Faktor - Faktor yang Mempengaruh Luas Pengungkapan Sukarela dalam Laporan Tahunan”. Jurnal Ilmiah Mahasiswa Ekonomi Akuntansi. Vol. 2, No. 1, Hal 63-72.

Krishna, Made Satriajaya. (2013). "Tingkat Likuiditas, Leverage, ukuran Perusahaan, Reputasi Kantor Akuntan Publik terhadap Pengungkapan Sukarela pada Manufaktur di Bursa Efek Indonesia”. E-Jurnal Akuntansi Universitas Udayana. ISSN 23028556.

Mishari M. Alfraih , and Abdullah M. Almutawa. (2017)."Voluntary disclosure and corporate governance: empirical evidence from Kuwait". International Journal of Law and Management, Volume: 59 Issue: 2, 2017.

Mohamed. (2013). "The determinants of corporate voluntary disclosure policy: Evidence from the Abu Dhabi Securities Exchange (ADX)". Journal of Accounting in Emerging Economies, Volume: 7 Issue: 2.

Nancy, Yunita. (2012). "Pengaruh Corporate Governance Terhadap Pengungkapan sukarela dan Biaya Hutang”. Jurnal Ilmiah Mahasiswa Akuntansi. Vol. 1. No 1.

Novita, Irwanto. (2013). "Luas Pengungkapan Sukarela, Asimetri Informasi, dan Biaya Modal Ekuitas". Jurnal Airlangga.

Nurrunabi, Hosein. (2012). "The voluntary disclosure of internet financial reporting (IFR) in an emerging economy: a case of digital Bangladesh". Journal of Asia Business Studies, Volume: 6 Issue: 1.

Poh Ling Ho, and Taylor. (2013). "Corporate governance and different types of voluntary disclosure: evidence from the Malaysia listed firm”. Pacific Accounting Review, Vol: 25, Issue: 1.

Rachmawati, Sistya. (2016). "Pengaruh Pengungkapan Sukarela dan Pengungkapan Tanggung Jawab Sosial Terhadap Koefisien Laba". Media Riset Akuntansi, Auditing \& Informasi. Vol. 6. No. 2.

Santoso, Singgih. (2014). "Statistik Nonparametrik: Konsep dan Aplikasi dengan SPSS". Jakarta, Elex Media Computindo.

Wen Qu. 2013. "A study of voluntary disclosure of listed Chinese firms - a stakeholder perspective". Managerial Auditing Journal, Volume: 28 Issue: 3. 
Wijayanti, Wahyuni. (2013). Analisis Pengaruh Corporate Governance dan Karakteristik Perusahaan terhadap Pengungkapan Sukarela dalam Laporan Tahunan (Studi pada Perusahaan Manufaktur Go Public yang Terdaftar di BEI). Jurnal UIN.

Wulandari, Laksito. (2015). " Analisis Faktor - Faktor yang Mempengaruhi Luas Pengungkapan Informasi Sukarela pada Laporan Keuangan Tahunan”. Diponegoro Journal of Accounting. Vol. 4, No. 3, Hal 1-9.

www.sindonews.com. Diakses pada tanggal 21 Agustus 2018. 